\title{
Nuclear Receptor Coactivator 6
}

National Cancer Institute

\section{Source}

National Cancer Institute. Nuclear Receptor Coactivator 6. NCI Thesaurus. Code C33997.

Nuclear receptor coactivator 6 (2063 aa, $\sim 219 \mathrm{kDa}$ ) is encoded by the human NCOA6 gene. This protein plays a role in the activation of gene transcription. 